\title{
E Sナノファイバインプリント犠牲樹脂型ナノ粉末印刷による マイクロ構造体の作製
}

\section{Fabrication of micro-structured parts by nanopowder printing using ES-nanofiber imprinting plastic mold}

\author{
Kazuaki NISHIYABU*1 and Jiro KAWAKAMI ${ }^{* 2}$ \\ ${ }^{* 1,{ }^{* 2}}$ Department of Mechanical Engineering, Faculty of Science and Engineering, Kinki University \\ 3-4-1 Kowakae, Higashiosaka-shi, Osaka 577-8502, Japan
}

\section{Received 12 November 2014}

\begin{abstract}
This study aims to develop an eco-friendly fabrication method for micro-structured parts with high aspect ratio. To achieve this purpose, nanopowder printing (nPP) process was adopted to the plastic mold with microstructures produced by electrospinning nanofiber imprinting (ES-NFI) method. A novel method named as ES-NFI sacrificial plastic mold nanopowder printing (ES-NFI/nPP) was proposed and demonstrated in this study. Micro plastic molds were prepared by ES-NFI method using Si forms that have various micro-structures including line and space (L/S) pattern, multi-pillars and holes. The effects of aspect ratio in microstructure on the shape transcription were investigated by changing $\mathrm{Si}$ forms from $1 \mu \mathrm{m}$ to $50 \mu \mathrm{m}$ wide for $10 \mu \mathrm{m}$ high. Also the composition of paste materials made from $\mathrm{TiO}_{2}$ nano-sized powder and PEG water-soluble binder was varied for the optimization. It was shown from the experimental results that the sintered part with microstructures of $50 \mu \mathrm{m}$ wide for $10 \mu \mathrm{m}$ high could be formed soundly, and it was also desirable to use the paste materials with lower content of binder polymer in keeping adequate viscosity. It was confirmed that ES-NFI/nPP method was a useful method for fabricating the micro-structured parts in the mass production.
\end{abstract}

Key words : Micro-structured part, Electrospinning nanofiber, Plastic mold, Nanopowder, Titanium oxide, Sintering, Viscosity, Transcription

\section{1. 緒言}

金属粉末射出成形（Metal Injection Molding，MIM）は，粉末治金（Powder Metallurgy，P/M）の圧粉焼結技術と プラスチック射出成形（Plastic Injection Molding，PIM）を組み合わせた複合の製造技術である（German，1984， German and Bose, 1997)。これは，金属粉末と大量のバインダを混練することによりペレットを調製し，バインダ の溶融温度まで加熱させて射出成形し, 所望の形状の成形体を得た後, 溶媒抽出または加熱分解によりバインダ を除去し，高温で加熱することにより焼結部品が得られる．そのため，MIM は高融点および高硬な機械加工困難 な材料をテーラーメイド組成で，複雑な三次元形状の金属部品を高い寸法精度で量産できる．さらに精密金型を 用いたマイクロサイズの金属部品を製造するマイクロ金属粉末射出成形（Micro metal injection molding, $\mu-M I M ）$ は有用性の高い製造技術である（Löhe and Haußelt, 2005, Piotter, 2012）。しかしながら，MIM の製品や構造のサイ ズが $1 \mathrm{~mm}$ 以下のスケールに近づくほど様々な技術課題がある（Nishiyabu，2012）．MIM の成形工程を考えると，

No.14-00604 [DOI:10.1299/transjsme.14-00604], J-STAGE Advance Publication date : 18 August, 2015

${ }^{*}$ 正員, 近畿大学 理工学部（干577-8502 大阪府東大阪市小若江 3-4-1）

*2 近畿大学 理工学部

E-mail of corresponding author: nishiyabu@mech.kindai.ac.jp 
マイクロスケールに近づくほど金属粉末の分散状態の均一性が求められる．また，金型のキャビティのサイズに 比べて粉末サイズが大きくなるため, 数 $\mu \mathrm{m}$ 程度の微小粒径の粉末を用いることにより金型への転写性が改善さ れると考えられるが，粉末間の抵抗が大きくなる．製品が複雑になると，成形時や脱脂・焼結時に変形や亀裂な どの欠陥が生じや寸くなり，寸法が微小であると寸法誤差が大きくなる. MIM のマイクロ化の技術は進んでいる が， $\mu$-MIM の高品質化については検討すべき課題がある. それらの問題を解決するため，マイクロ犠牲樹脂型イ ンサート金属粉末射出成形（Micro Sacrificial Plastic Mold Insert MIM, $\mu$-SPiMIM）が開発された（西慜他, 2010a, 2010b, 2011, 2013)。この $\mu$-SPiMIM プロセスの特徵は，金型の代わりに樹脂型を用いることである. 作製対象物 を反転させた樹脂型を金型内へインサートし，そこにMIM 原料を射出成形した後，MIM 成形体と樹脂型を一体 で離型し，そのまま脱脂・焼結を行う。脱脂時に樹脂型を除去するため離型の必要がなく, 取扱性も向上する. $\mu$-SPiMIM プロセスの適用により，金型を用いた MIM プロセスでは製造困難であった複雑な形状部品の作製も可 能になった。 しかしながら, 射出成形は薄いシート状の部品の成形が困難であり, 加圧および加熱による環境負 荷が少なくない，一方，粉末からなるペーストを用いた印刷により，大量かつ高速に電子部品や機器を製造する プリンテッドエレクトロニクス（Printed Electronics, PE）技術が注目されている（管沼，2010)。このPE 技術は配 線だけでなく, 表示デバイスやソーラーパネル，さらに微細部品の低コスト製造も期待されている.

本論は， $\mu$-SPiMIM プロセスの成形性と環境適合性を改善するため, 著者らが開発したエレクトロスピニング (Electrospining, 以後 ES と称す) ナノファイバインプリント（ES-NFI）樹脂型（西慜, 川上, 2015）を粉末印刷 に適用することを提案する.このプロセスを ES ナノファイバインプリント犠牲樹脂型ナノ粉末印刷 (ES-nanofiber Imprinting Sacrificial Plastic Mold Nanopowder Printing, ES-NFI/nPP）と称し，マイクロ構造体の新たな製造法の開発 を目的とした．本実験では，水溶性バインダと $\mathrm{H}_{2} \mathrm{O}$ の配合割合を変化させてナノサイズの $\mathrm{TiO}_{2}$ 粒子ペーストを 調製し，これを ES-NFI 樹脂型にコンタクト印刷して成形体を得た後，脱脂・焼結を得て焼結体を作製した。 こ の際，3 種類のマイクロ構造を有する ES-NFI 樹脂型のサイズを種々変化させ，それらの形状転写性を評価した。

\section{2. 製造方法および実験条件}

\section{$2 \cdot 1$ ES ナノファイパインプリント犠牲樹脂型ナノ粉末印刷法}

本研究で提案した ES-NFI/nPP 法の工程を図 1 に示寸. 本法は, 図 1(a)エレクトロスピニング法により作製した ナノファイバシートをインプリントにより樹脂型を作製し, 図 1(b)ナノ粒子とバインダにより調合したペースト を樹脂型にコンタクト印刷し, 図 1(c)溶媒脱脂により樹脂型を除去し, 図 1(c)成形体を脱脂・焼結を経て, 高ア スペクト比のマイクロ構造体を有する焼結体を得る製造プロセスである.

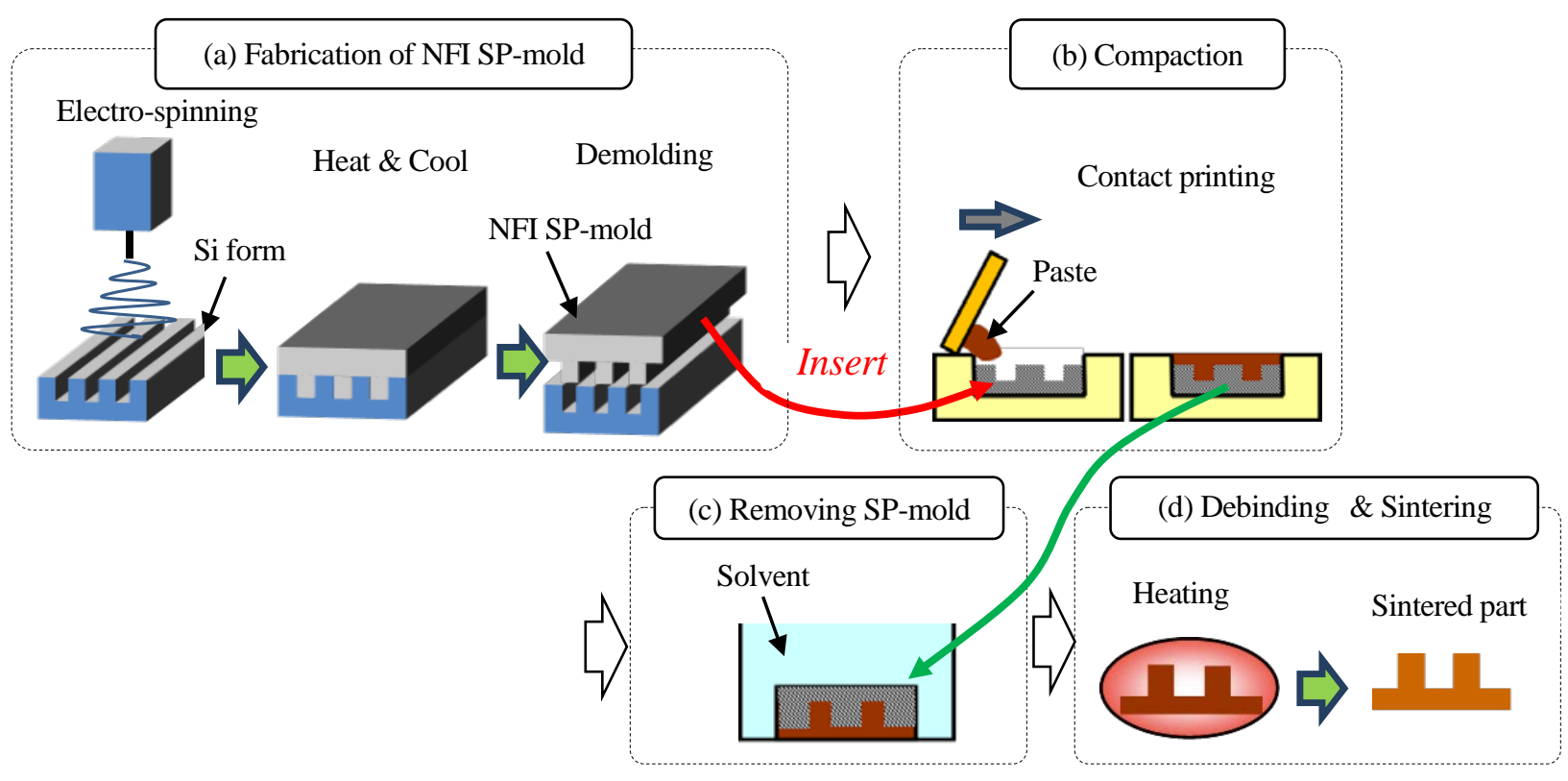

Fig.1 Flow of ES-NFI/nPP process. 
従来のインプリント法の技術水準を上回るための解決策として，インプリントに使用する樹脂フィルムを ES ナノファイバにより作製することを考案した．これは，ナノファイバ特有のマイクロフィブリル構造から由来す る ES-NFI 樹脂型への転写性効果を発現させることにより, 微細な構造体が得られることを特徵としている.

\section{$2 \cdot 2$ エレクトロスピニングナノファイバ樹脂型の作製法}

ナノファイバは, 直径数 $\mathrm{nm}$ から数百 $\mathrm{nm}$ 以下の極細緘維であり, 比表面積が大きく, 特殊な表面機能を有す るため，様々な分野への利用が期待されている．とりわけ，ES 法は，溶媒で溶解できるならば様々な材料に適用 可能であり，その紡糸溶液が細いノズルから押出される際に数十 $\mathrm{kV}$ 程度の高い電圧を印加させてナノファイバ が作製される．電気引力が紡糸溶液の表面張力を超え, 紡糸溶液のジェットがコレクターに向けて噴射する際に ジェット中の溶媒が徐々に揮発し，コレクターにシート状の不織布や一方向材が得られる. 印加電圧, 紡糸溶液 の樹脂濃度や送出し量などの紡糸条件を変化させることにより, 種々の直径のナノファイバを作製できる

(Ramakrishna, 2005, 山下, 2007, Wendorff, et al., 2012).

ES-NFI 法によるマイクロ樹脂型の製造法の模式図を図1(a)に示す. 使用材料は，ポリメタクリル酸メチル樹脂 (シグマアルドリッチ㑣， Polymethylmethacrylate，以後 PMMA と称す）を N,N-ジメチルホルムアミド（キシダ 化学(侏), N,N-dimethylmethanamide, 以後 DMF と称寸) とクロロフォルム (キシダ化学(侏), Chloroform, 以後 $\mathrm{CHCl}_{3}$ と称す）で溶解した紡糸溶液であり，樹脂濃度を $17 \mathrm{mass} \%$ した。この紡糸溶液を ES ナノファイバ装置（侏メ ック，NANON-01A）のシリンジに注入し，1.8ks 間電場を与えて紡糸し，図 2 に示すような Si 型の表面にナノフ アイバを製膜した. 図 2(a)は Si 型の全体の形状を示し, 図 2(b)L/S パターン, 図 2(c)円柱および図 2(d)円孔に対 して, 高さ $h=10 \mu \mathrm{m}$ で幅 $w=1 \sim 50 \mu \mathrm{m}$ に変化させた微細構造を有している. この Si 型上に製膜したナノファイバ を熱風乾燥機（い寸心゙製作所, MRN-111）で $140^{\circ} \mathrm{C}, 1.8 \mathrm{ks}$ 間加熱し, 室温まで泠却した. この段階でのナノファ イバは薄膜であり取扱い性にそしいため, ES ナノファイバの作製に使用した紡糸溶液をナノファイバの被膜の上 に塗布し, $170^{\circ} \mathrm{C}$ に加熱後に室温まで泠却し, 型から外して ES-NFI 樹脂型を得た.

(b) Line-space

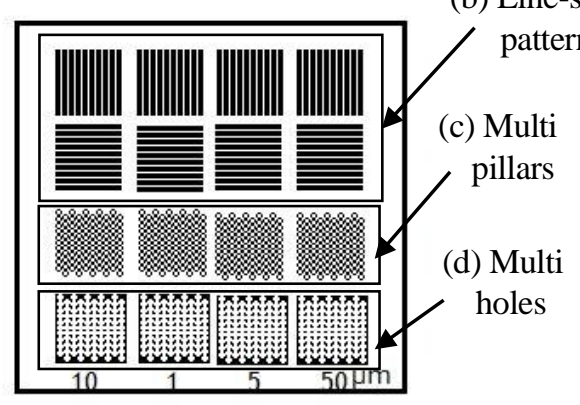

(a) Appearance

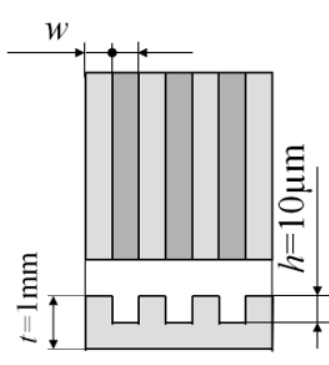

(b) Line-space pattern

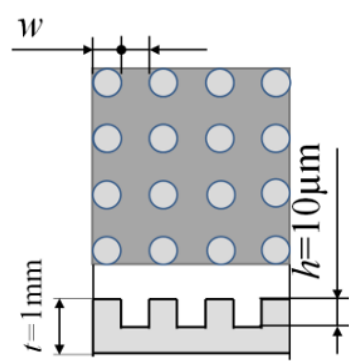

(c) Multi pillars

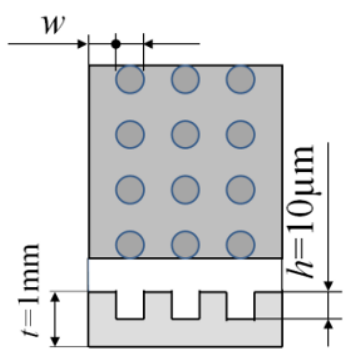

(d) Multi holes

Fig.2 Dimensions of Si forms used for ES-nanofiber imprinting.

\section{$2 \cdot 3$ 使用材料および配合割合}

粉末印刷に使用した原料は, 図 3 に示すような平均粒径 $200 \mathrm{~nm}$ の酸化チタン粒子（和光純薬工業(株， $\mathrm{TiO}_{2}$, 試 薬 CAS.NO 1317-80-2) に水溶性樹脂のポリエチレングリコール (PEG, 分子量 20,000, キシダ化学(侏), 試薬 CAS.NO 25322-68-3）を $\mathrm{H}_{2} \mathrm{O}$ で溶解混合したペーストである。これは，自転·公転ミキサー（侏THINKY，AR-100）を用 いて室温で攪捧および脱泡して作製した。 その際，ペーストの粘度は回転型粘度計（ブルックフィールド, HBDV-II+PCP） にコーンスピンドル（ブルックフィールド，CPA-52Z）を用いて測定した。ペーストの粘度が低 いほど微細な構造体への充填が容易になるが，粘度が低すぎるとペーストの流出や保形性の低下が生じ，形状安 定性が劣る. そのため, 高い形状精度と高密度の両方を満足する焼結体を得るには微細な型への充填性を確保し つつ，できるだけ粉末密度の高いペーストの配合割合を選定する必要がある.

本論では, 成形性と形状転写性の観点から, 表 1 に示すように $\mathrm{TiO}_{2}$ 粉末割合を $40 \mathrm{mass} \%$ となるように, $\mathrm{TiO}_{2}$ 粉末と PEG の配合量を一定として, $\mathrm{H}_{2} \mathrm{O}$ の添加量を種々変化させたところ, 図 4 に示すようにペーストの粘度が 大きく変化した. $\mathrm{TiO}_{2}$ 粉末割合が 40mass\%の 40-L，40-M および 40-H で成形体を作製した結果，40-M のペース 
トが適正であることが分かった，そのため，40-M のペーストの粘度を変化させずに PEG の配合量を減らし，よ り高密度な焼結体が得られると思われる $\mathrm{TiO}_{2}$ 粉末割合 $56 \mathrm{mass} \%$ の 56-M のペーストを用いて成形体および焼結体 を作製して，これを評価対象とした。

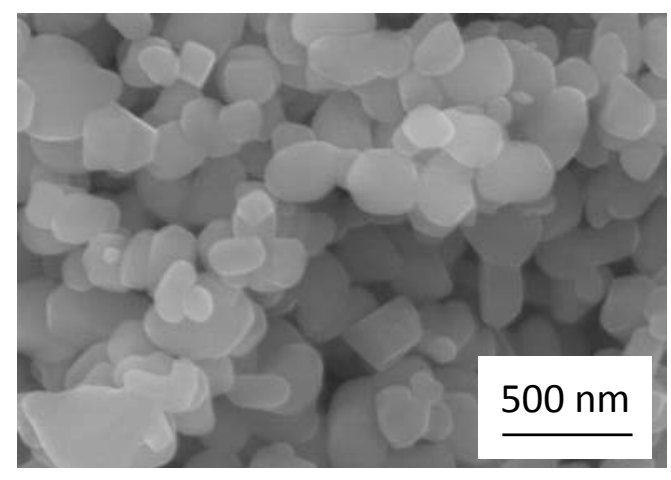

Fig.3 SEM image of $\mathrm{TiO}_{2}$ particle used.

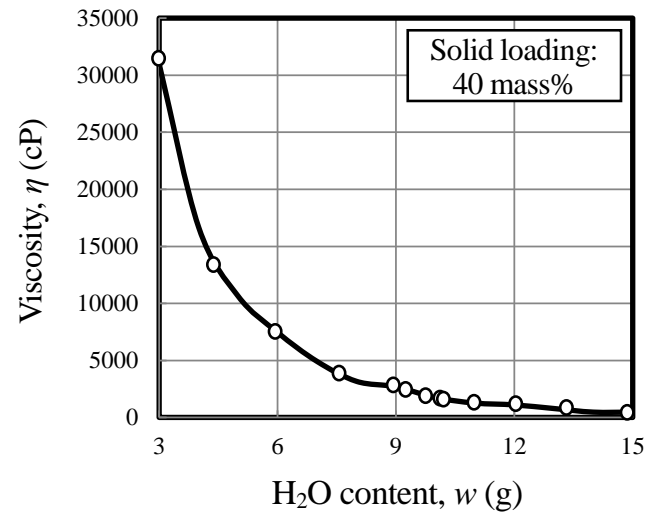

Fig.4 Viscosity of pasts with various $\mathrm{H}_{2} \mathrm{O}$ contents.

Table 1 Composition of paste used for imprinting

\begin{tabular}{|c|c|c|c|c|c|c|c|c|}
\hline \multirow{2}{*}{$\begin{array}{l}\text { Composition } \\
\text { ID }\end{array}$} & \multirow{2}{*}{$\frac{\text { Solid loading }}{\text { (mass\%) }}$} & \multicolumn{2}{|c|}{$\mathrm{TiO}_{2}$} & \multicolumn{2}{|c|}{ PEG } & \multicolumn{2}{|c|}{$\mathrm{H}_{2} \mathrm{O}$} & \multirow{2}{*}{$\frac{\text { Viscosity }}{\eta(\mathrm{cP})}$} \\
\hline & & (g) & (mass\%) & (g) & (mass\%) & (g) & (mass\%) & \\
\hline (a) 40-L & \multirow{3}{*}{40} & \multirow{3}{*}{2.0} & 12.9 & \multirow{3}{*}{3.0} & 19.4 & 10.5 & 67.7 & 1270 \\
\hline (b) $40-\mathrm{M}$ & & & 13.3 & & 20.0 & 10.0 & 66.7 & 1746 \\
\hline (c) $40-\mathrm{H}$ & & & 13.8 & & 20.7 & 9.5 & 65.5 & 1905 \\
\hline (d) $56-\mathrm{M}$ & 56 & 2.0 & 14.7 & 1.6 & 11.8 & 10.0 & 73.5 & 1746 \\
\hline
\end{tabular}

\section{$2 \cdot 4$ 成形体と焼結体の作製および評価方法}

成形体の作製工程を図 5 に示寸. 図 5(a)のような手刷り卓上スクリーン印刷機（㑣亲オッテクジャパン， NJ-15PHP) をコンタクト印刷仕様に改良し，図 5(b)および(c)に示すように ES-NFI 犠牲樹脂型の上に $\mathrm{TiO}_{2}$ 粉末の ペーストをコンタクト印刷した．その $\mathrm{TiO}_{2}$ 成形体を $\mathrm{Al}_{2} \mathrm{O}_{3}$ 板に置き，卓上マッフル炉（山田電機森，YF-120-PS） で, 大気中で炉内温度 $300^{\circ} \mathrm{C}$ で $1.8 \mathrm{ks}$ 間加熱脱脂した後, 大気中で炉内温度 $500^{\circ} \mathrm{C}$ で $1.8 \mathrm{ks}$ 間保持し, 焼結体を得 た. 得られた成形体および焼結体の表面形態は走査電子顕微鏡（森日立ハイテクノロジーズ，SU1510）を用 いて観察し，そのマイクロ構造体の断面形状はレーザ顕微鏡（オリンパス怢，OLS4100）を用いて，ほぼ中 央部の任意の個所を数点測定し, その代表的な断面形状からマイクロ構造体を作製するための最適条件を探 索した.

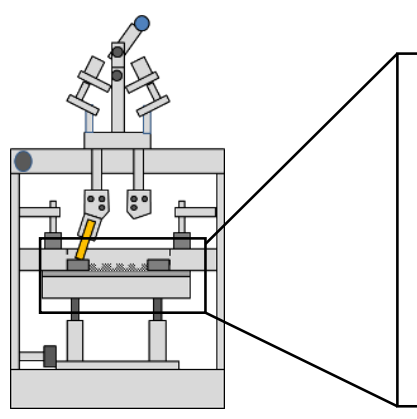

(a) Appearance

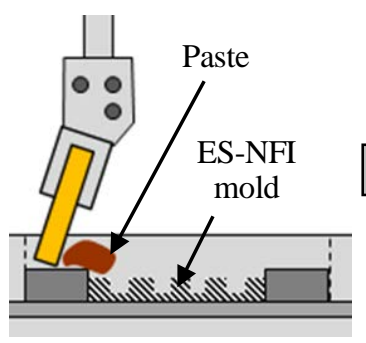

(b) Before printing

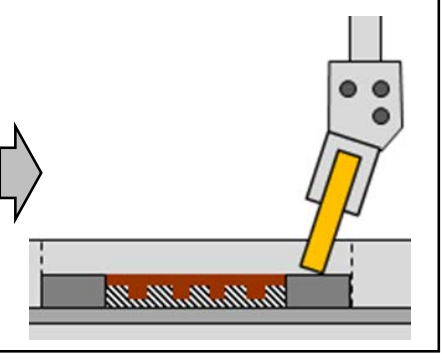

(c) After printing

Fig.5 Appearance of contact printing process. 


\section{3. 実験結果および考察}

\section{$3 \cdot 1$ 成形体と焼結体の形状転写性に及ぼす構造サイズの影響}

図 6 は, マイクロ構造体の幅を $w=1 〜 50 \mu \mathrm{m}$ まで変化させた L/S パターンの Si 型を用いて作製した(i)ES-NFI 樹 脂型，および $\mathrm{TiO}_{2}$ 粉末印刷により得られた(ii)成形体と(iii)焼結体の表面の SEM 像を示す. ES-NFI 法により作製 したマイクロ樹脂型は， $w=1 〜 50 \mu \mathrm{m}$ のどのサイズの構造体に対しても良好な転写性を示していることが分かる. (i)ES-NFI 樹脂型を溶媒で除去することにより，(ii)に示すような微細構造を表面に持つ成形体が得られた．図 6(a) $w=1 \mu \mathrm{m}$ の成形体には直線性の欠如や隣接する凸部との接触などの欠陥が見られるが，図 6(b) $w=5 \mu \mathrm{m}$ 以上では 脱バインダによる微視的な亀裂が見られる程度であり, 概ね(i)ES-NFI 樹脂型の形状通りに転写されている. 一方, (iii)焼結体の場合，焼結収縮により成形体のサイズよりも線幅が小さくなっており，図 6(a)w=1 $\mu \mathrm{m}$ では線どうし が接触して線間の隙間が消失しているが, 図 6(b)w=5 $\mu \mathrm{m}$ 以上では成形体の形状が健全に保持されている. ただし， 印刷法では射出成形法のように高い成形圧力を付与できないため, 成形体の密度を上げることは困難であり，高

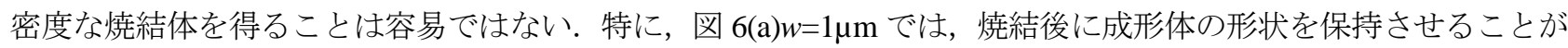
極めて困難なサイズであることが分かった.

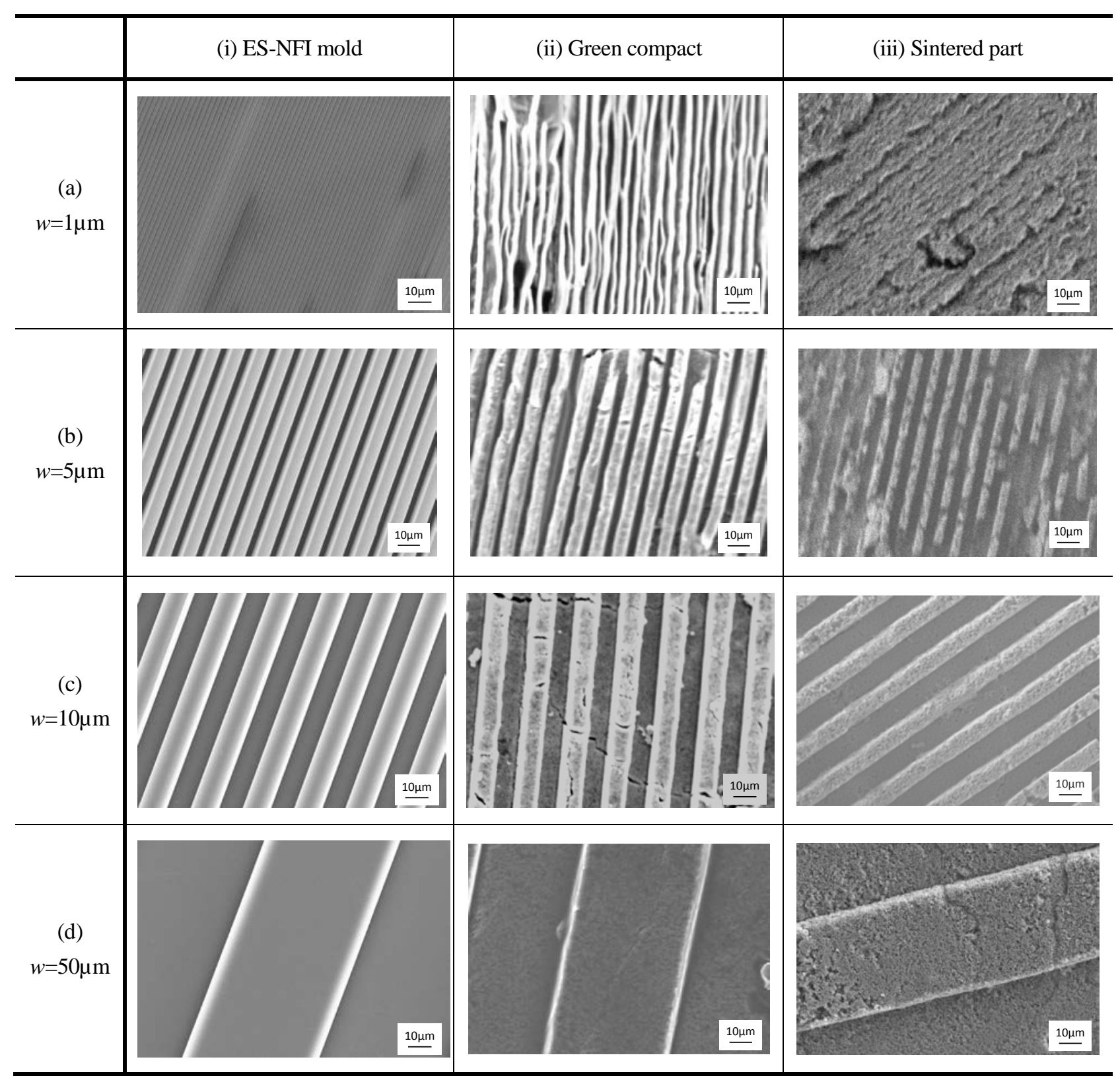

Fig.6 SEM images of micro-structured parts with various sized line and space patterns. 
図 7 は，マイクロ構造体の幅を $w=1 〜 50 \mu \mathrm{m}$ まで変化させた円柱の Si 型を用いて作製した(i)ES-NFI 樹脂型，お よび $\mathrm{TiO}_{2}$ 粉末印刷により得られた(ii)成形体と(iii)焼結体の SEM 像を示す. 円柱の $\mathrm{Si}$ 型を用いているため,

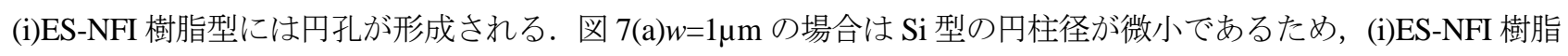
型には明瞭な円孔が見られない. そのため, (ii)成形体および(iii)焼結体も円柱の形状が得られていない. 図

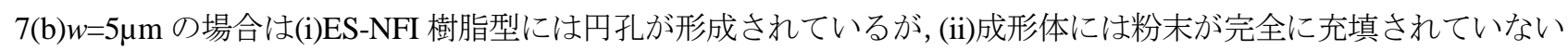

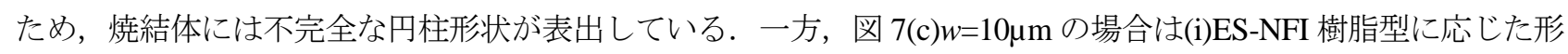
状の成形体が得られているが，先端部でやや未充填な箇所も見られる. その結果として，(iii)焼結体の形状が不安

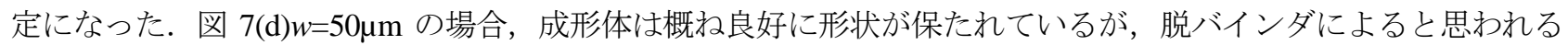
大きな亀裂が見られ，(iii)焼結体では凸部にも多数の亀裂が発生した箇所が見られる．これは，より高温で焼結す ることにより焼結密度を向上させることも可能であるが，円柱の角縁部の形状を保持することは難しいため，成 形体の粉末充填密度を向上させることにより改善することが望ましいと考える. しかし，ナノスケールの微粉末 を用いた場合は, 粉末間の接触抵抗が大きいため, 粘度上昇を抑えて成形性の低下を抑制するにはバインダ量が 必然的に多く配合することになり，成形体密度を上げることは困難であるため，さらに適正なぺーストの調製と 焼結条件の探究が必要である.

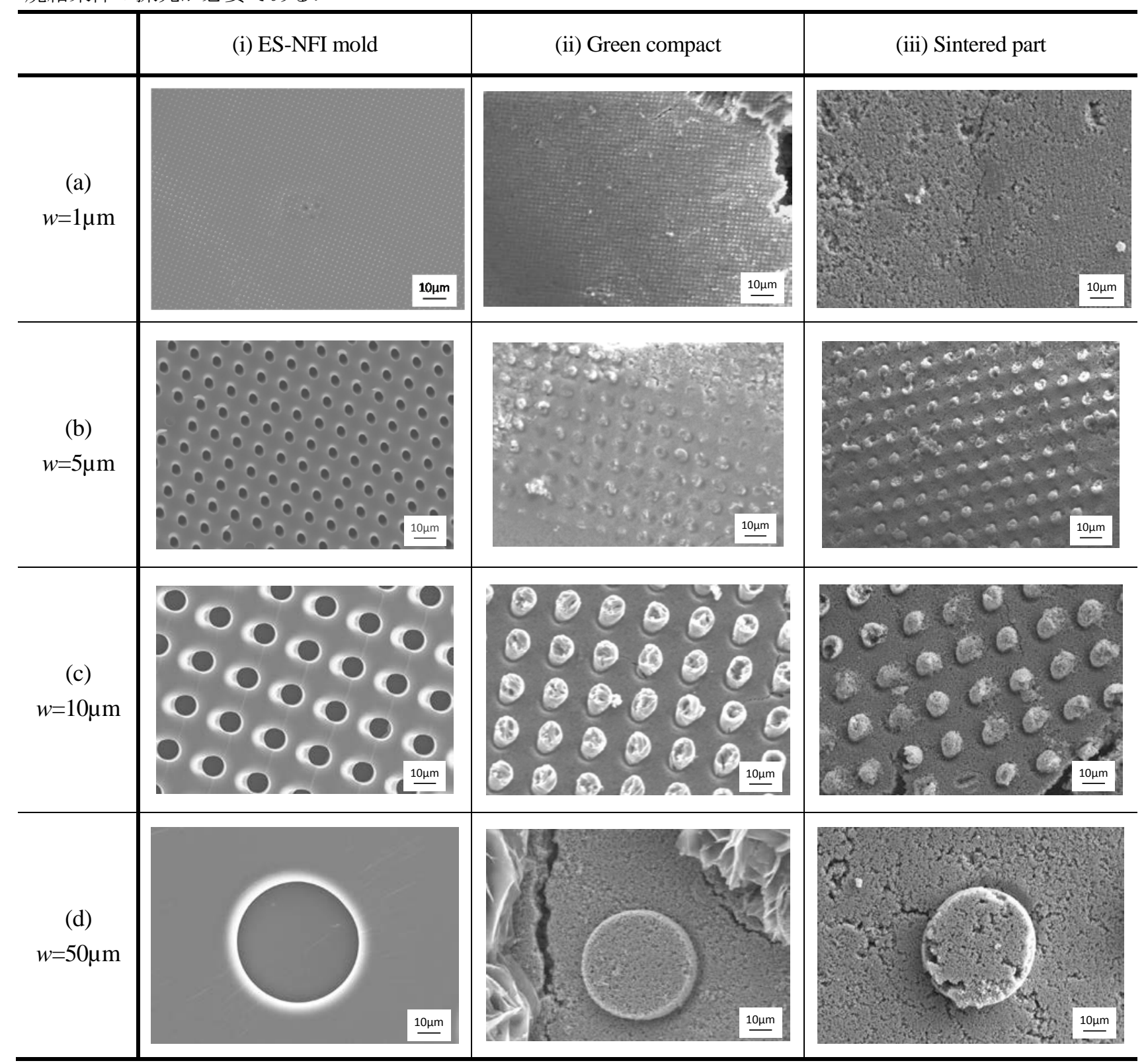

Fig.7 SEM images of micro-structured parts with various sized pillar patterns. 
図 8 は，マイクロ構造体の幅を $w=1 〜 50 \mu \mathrm{m}$ まで変化させた円孔の Si 型を用いて作製した(i)ES-NFI 樹脂型，お よび $\mathrm{TiO}_{2}$ 粉末印刷により得られた(ii)成形体と(iii)焼結体の SEM 像を示寸. 円孔の $\mathrm{Si}$ 型を用いているため, (i)ES-NFI 樹脂型には円柱が形成される. 図 8(a)w=1 $1 \mu \mathrm{m}$ の場合, (i)ES-NFI 樹脂型にやや欠損している箇所が見ら れるが，総じて円孔の角縁部には鋭角な形状が転写されており，(i)ES-NFI 樹脂型には凸形状を良好に転写されて いる.しかし，(ii)成形体の一部および(iii)焼結体の全体に円孔が見られない箇所があり，幅 $1 \mu \mathrm{m}$ ，高さ $10 \mu \mathrm{m} の$ 円孔が密に配置された間の狭い間隙に $\mathrm{TiO}_{2}$ 粉末ペーストが充填し難いことが分かった. 図 8 (b)w=5 $\mu \mathrm{m}$ の場合, (i)ES-NFI 樹脂型には円柱が良好に形成されているが，(ii)成形体の一部に円孔が欠いている箇所も見られる.しか し，(iii)焼結体には成形体の円孔径よりも大きい内径の円孔が形成されている。これは，(ii)成形体にはバインダ の偏在や浸多出しが生じていたが，脱脂によりバインダが除去され，さらに焼結により円孔の周囲のセル構造体 が収縮したためであると思われる，試験片全体の焼結収縮により，内在寸る局所的な円孔の内径は減じると推察 される．しかし，本焼結体に用いた粉末はナノサイズの微粒子であるため，成形性を確保するためバインダの配 合割合が高く, また焼結度も高くないため, このような現象が生じたと推察される. このメカニズムについては, 成形体密度を考慮した焼結収縮の解析等を用いて, より詳細な探究が必要であるため, 今後の課題とする. 一方,

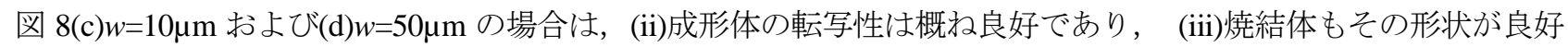
に保持されている.これらの焼結体には微細な気孔が多数見られるが，これは焼結条件の適正化により改善する ことが可能であると思われる。

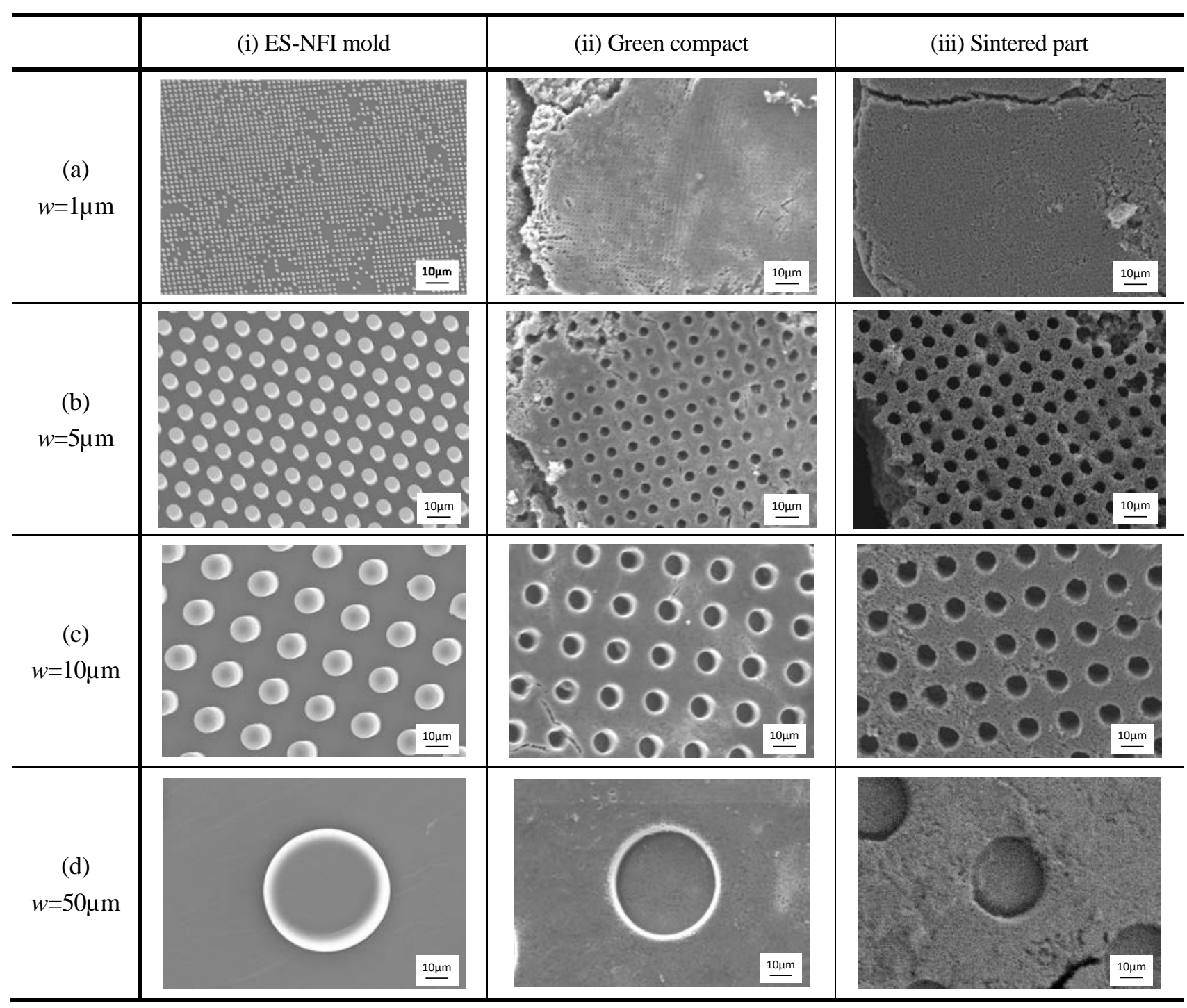

Fig.8 SEM images of micro-structured parts with various sized hole patterns. 


\section{$3 \cdot 2$ ペーストの粘度が成形体の形状に及ほす影響}

$\mathrm{TiO}_{2}$ 粉末割合が 40 mass\%のペーストに $\mathrm{H}_{2} \mathrm{O}$ の添加量を種々変化させて, 異なる粘度を持つペーストを調製した. これらのペーストを用いてコンタクト印刷して成形体を作製し，ペーストの粘度の違いが成形体の表面のマイク 口構造体の断面形状に及ぼす影響を調査した. 断面形状は, ES-NFI 樹脂型を加熱脱脂により除去した後の成形体 の表面をレーザ顕微鏡により計測した.

図 9 は, 幅 $w=10 \mu \mathrm{m}$, 高さ $h=10 \mu \mathrm{m}$ の L/S パターンの ES-NFI 樹脂型, およびペーストの粘度を $\eta=1270 \mathrm{cP}, \eta=1764 \mathrm{cP}$ および $\eta=1905 \mathrm{cP}$ の 3 種類に変化させた場合の成形体の代表的なマイクロ構造体の断面形状を示す. 図 9(a)の ES-NFI 樹脂型の断面形状は Si 型の断面形状を良好に転写しているが，高さ方向に $1 \sim 2 \mu \mathrm{m}$ 程度伸長している. これは，ES-NFI 樹脂型が Si 型から離型する際に，型との接触抵抗により高さ方向に引き延ばされたことが原因 と考えられる．幅方向は，樹脂の固化収縮量と $\mathrm{Si}$ 型の拘束から開放された伸長量が相殺され，Si 型の幅 $w=10 \mu \mathrm{m}$ と大差ない值が得られたと思われる. 低粘度の図 9(b) $\eta=1270 c P$ の場合, 先端部の形状が図 9(a)ES-NFI 樹脂型と大 きく異なっており，ペーストが充填不足であることが分かる．これは先端の角縁部に $\mathrm{H}_{2} \mathrm{O}$ の浸み出しが生じ，離 型後に $\mathrm{H}_{2} \mathrm{O}$ が揮発したためであると考えられる. 一方, 図 9(c) $\eta=1746 \mathrm{cP}$ の場合, 高さ方向への伸長が大きいが, 高さ方向への奥深い溝部分にペーストが充填されており, 比較的良好な成形性を示していると言える. しかし, 高粘度の図 9(d) $\eta=1905 \mathrm{cP}$ の場合, 凸部の高さが低く, 先端部は平坦であり, 溝深さ方向へのペーストの充填が不 十分であることが明らかであるため，不適正な調製条件であると言える.

以上の実験結果から, 幅 $w=10 \mu \mathrm{m}$, 高さ $h=10 \mu \mathrm{m}$ の L/S パターンにおいては, $\eta=1746 \mathrm{cP}$ 程度の粘度のペースト を用いて樹脂型にコンタクト印刷を行うと，微細なマイクロ構造体に対しても形状転写性に優れた成形体が得ら れることが分かった.

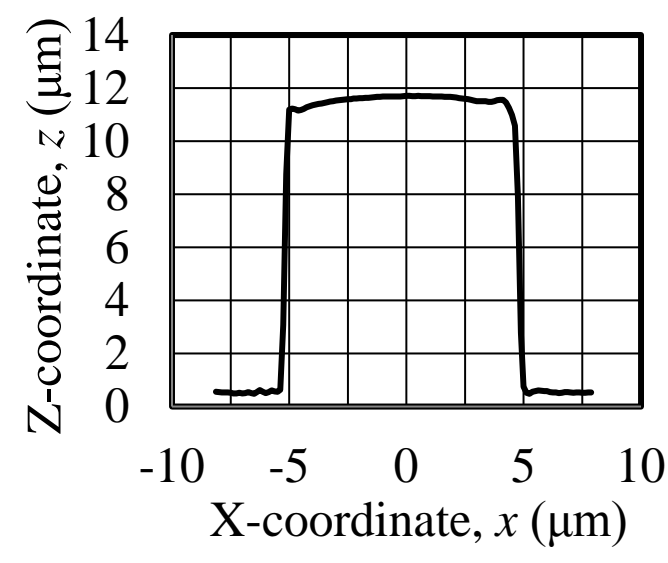

(a) ES-NFI mold

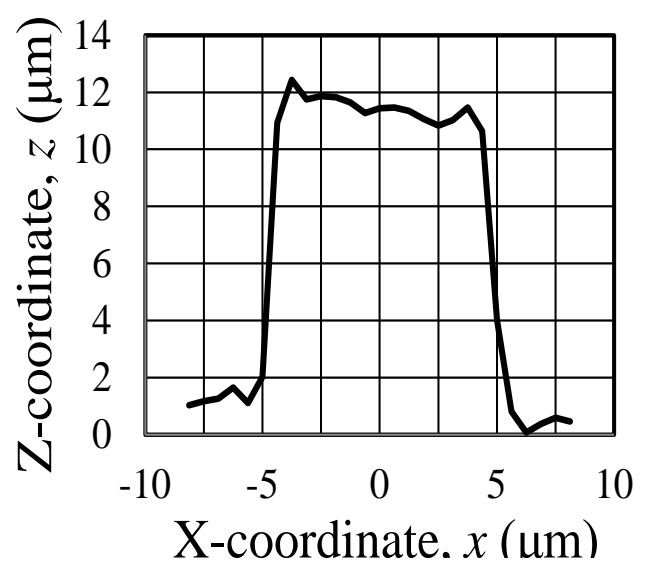

(c) Green compact $(\eta=1746 \mathrm{cP})$

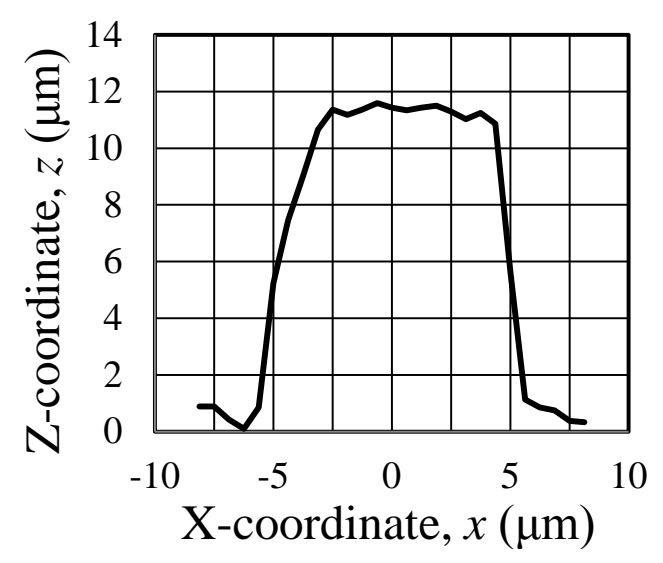

(b) Green compact ( $\eta=1270 \mathrm{cP})$

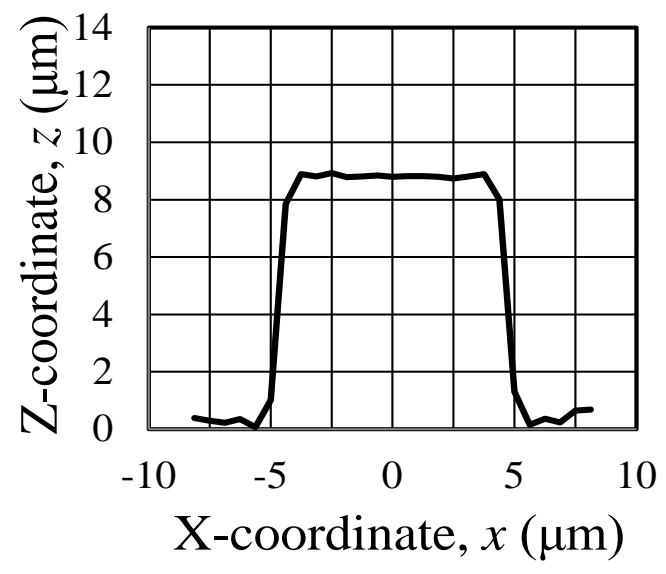

(d) Green compact $(\eta=1905 \mathrm{cP})$

Fig.9 Cross-sectional shapes of ES-NFI mold and green compacts fabricated using past with various viscosities. 


\section{$3 \cdot 3$ バインダの配合割合が焼結体の形状に及ほす影響}

前節で得られた適正なペースト粘度である $\eta=1746 \mathrm{cP}$ で作製された成形体を焼結し, その断面形状を評価した. さらに，形状転写性の高い焼結体を得ることを目的に，PEGの配合割合を減少させ，粉末割合の高いペーストを 調製し，同様に成形体および焼結体を作製し，その効果を調査した.

図 10 は，粉末割合が 40mass\%のペーストを用いて作製した L/S パターンの成形体および焼結体の断面形状を 示す. 図 10(a)成形体では ES-NFI 樹脂型に近い角形の断面形状が得られたが，図 10(b)焼結体では先端の尖った形 状になり，形状精度の低い結果が得られた。この理由は，成形体の先端部は断面形状では矩形であり，角縁部に はペーストが充填されているが，その角縁部はバインダが過多の状態であるため, 脱脂・焼結後にそれらのバイン ダが消失し，焼結収縮により先端の尖った形状になったと思われる.

図 11 は, 粉末割合を 56mass\%まで高めたペーストを用いて作製した L/S パターンの成形体および焼結体の断面 形状を示す。この 56 mass\%を超える割合の高い粉末割合のペーストを用いて成形体の作製を試みたが，バインダ である PEG の配合割合が小さいため, 粉末間の結合力がそしく, 成形体の形状を保持することができなかった. 図11(a)の成形体と図11(b)焼結体の形状は類似しており, 突起形状が形成されており, 図 11(b)焼結体の方が図 11(a) 成形体よりも若干小さく，焼結収縮していることが分かる.

以上の実験結果から, 幅 $w=10 \mu \mathrm{m}$, 高さ $h=10 \mu \mathrm{m} の \mathrm{~L} / \mathrm{S}$ パターンにおいては, 前節の $\eta=1746 \mathrm{cP}$ 程度の粘度を保 持したままバインダの配合割合をさらに減少させ，粉末割合を可能な限り高めたペーストを調製する，これを樹 脂型にコンタクト印刷して成形体を作製し, 脱脂・焼結を経てマイクロ構造を有する焼結体を製造することが可 能であることが実証された。

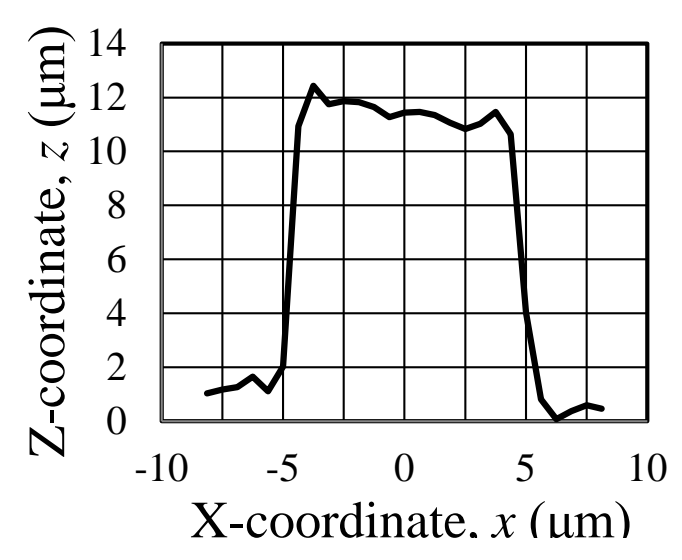

(a) Green compact

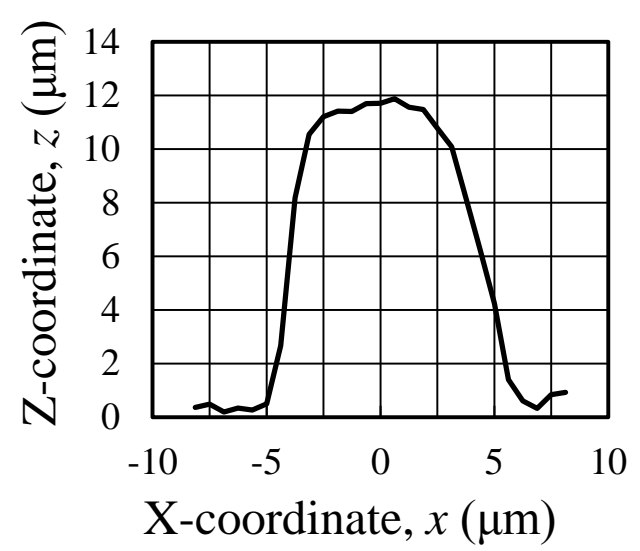

(b) Sintered part

Fig.10 Cross-sectional shapes of green compact and sintered part fabricated using past with 40mass\% solid loading.

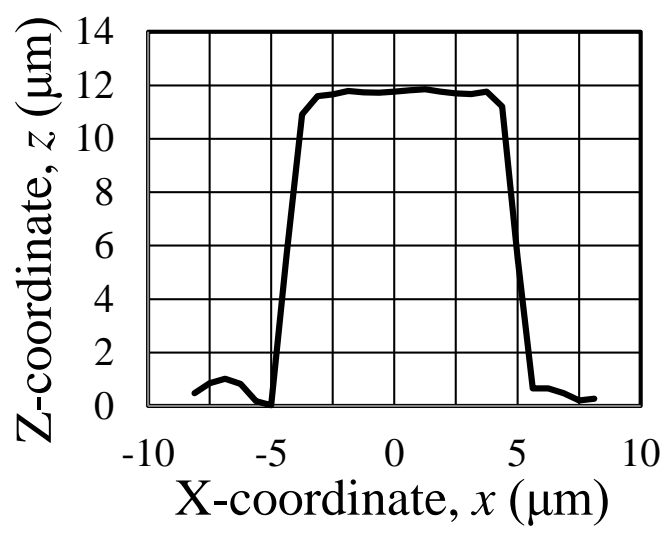

(a) Green compact

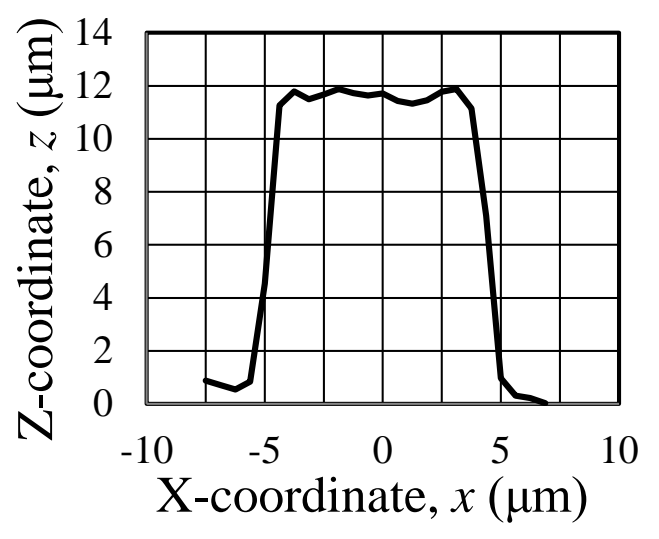

(b) Sintered part

Fig.11 Cross-sectional shapes of green compact and sintered part fabricated using past with 56mass\% solid loading. 


\section{4. 緒言}

本論は，マイクロ構造体を高い生産効率，かつ低い環境負荷で製造することを目的に，エレクトロスピニング ナノファイバを $\mathrm{Si}$ 型に噴霧し，これを溶融および離型により得られたマイクロ樹脂型を作製する ES-NFI 法と， ナノ粒子とバインダにより調合したペーストを用いたナノ粉末印刷法を合わせた ES ナノファイバインプリント 犠牲樹脂型ナノ粉末印刷（ES-NFI/nPP）法を提案した.

ナノサイズの $\mathrm{TiO}_{2}$ 粒子と水溶性バインダにより調製したペーストの配合割合を種々変化させ， ES-NFI 樹脂型 に印刷して得られた成形体および, その焼結体の形状転写性を評価した. 幅 $10 \mu \mathrm{m}$ 高さ $10 \mu \mathrm{m}$ の L/S パターンで, $\mathrm{H}_{2} \mathrm{O}$ の添加量を種々変化させ，断面形状を比較したところ，ペーストの粘度が 1746cP 程度で ES-NFI 樹脂型に良 好に充填されることが分かった．また， $\mathrm{TiO}_{2}$ 粉末割合を高くした場合，幅 $10 \mu \mathrm{m}$, 高さ $10 \mu \mathrm{m}$ のマイクロ構造体

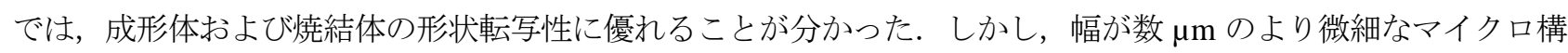
造体では，成形体の充填性が十分ではないために，焼結体では形状転写性の低下による形状不良や亀裂などの欠 陥が見られた。

今後, さらなるバインダの成分の適正化や印刷時の圧力付与が可能になれば，幅が数 $\mu \mathrm{m}$ 程度のマイクロ構造 体においても成形時の形状安定性に優れ, 高密な成形体が得られる. また, 焼結体も成形体の形状品質が改善さ れれば幅が数 $\mu \mathrm{m}$ 程度のマイクロ構造体を持つ焼結体が得られる可能性がある. このような観点から, 本論で提 案した ES-NFI/nPP 法は実用性の高い優れたマイクロ構造体製造法であると結論付けられる。

\section{謝 辞}

本研究の一部は科研費（26420031）および「文部科学省私立大学戦略的研究基盤形成支援事業（平成 24 年〜平 成 26 年)」の助成を受けたものであることを記し，関係各位に深謝申し上げます．また，実験装置の提供にご協 力を頂いた太盛工業侏田中茂雄氏に感謝申し上げます.

\section{文献}

German, R. M., Powder metallurgy science, 2nd edition, Metal Powder Industries Federation (1984).

German, R. M. and Bose, A., Injection molding of metals and ceramics, Metal Powder Industries Federation (1997).

管沼克昭，プリンテッドエレクトロニクス技術最前線，シーエムシー出版 (2010).

Löhe, D. and Haußelt, J., Advanced micro \& nanosystems Vol.3, Microengineering of metals and ceramics: Part I: Design, tooling, and injection molding (2005a), Wiley-VCH.

Löhe, D. and Haußelt, J., Advanced micro \& nanosystems Vol.4, Microengineering of metals and ceramics. Part II, Special replication techniques, automation, and properties (2005b), Wiley-VCH.

西繁和明，柿下健一，田中茂雄，レジスト薄膜インサート金属粉末射出成形によるマイクロ構造体の作製と粉末 粒径の影響，日本機械学会論文集 A 編，Vol.76，No.761 (2010a)，pp.75-80.

西篥和明, 柿下健一, 田中茂雄, 金属粉末射出成形により作製した銅焼結体の諸特性に及ぼすマイクロ/ナノ粉末 割合の影響，日本機械学会論文集 A 編，Vol.76，No.767 (2010b)，pp.996-1001.

西篥和明, 田邊大貴, 鹿子泰宏, 田中茂雄, ナノ銅粉末を用いた NIL 犠牲樹脂型インサート MIM によるマイク 口構造体の作製，日本機械学会論文集 A 編，Vol.77，No.780 (2011)，pp.1378-1387.

Nishiyabu, K., Micro metal powder injection molding, Some critical issues for injection molding, edited by Wang J., InTech, Chapter 5 (2012), pp.105-130.

西笅和明, 田邊大貴, 鹿子泰宏, 田中茂雄, マイクロおよびサブマイクロ銅粉末射出成形体の脱脂・焼結挙動, 日本機械学会論文集 A 編, Vol.79, No.807 (2013), pp.1593-1603.

西䈣和明, 川上慈朗, エレクトロスピニングナノファイバによるマイクロインプリント樹脂型の複製, 日本機械 学会論文集, Vol.81, No.824 (2015), DOI:10.1299/transjsme.14-00571.

Piotter, V., Micro Metal injection molding (MicroMIM), Handbook of metal injection molding, edited by Heaney D., Woodhead Publishing, Chapter 13 (2012), pp.307-337. 
Ramakrishna, S., An Introduction to electrospinning and nanofibers (2005), World Scientific Publishing Company.

山下義裕，エレクトロスピニング最前線一ナノファイバー創製への挑戦一, 繊維社 (2007).

Wendorff, J.H., Agarwal, S. and Greiner, A., Electrospinning: materials, processing, and applications (2012), Wiley-VCH.

\section{References}

German, R. M., Powder metallurgy science, 2nd edition, Metal Powder Industries Federation (1984).

German, R. M. and Bose, A., Injection molding of metals and ceramics, Metal Powder Industries Federation (1997).

Kannuma, K., Advanced printed electronics, CMC publishing (2010) (in Japanese).

Löhe, D. and Haußelt, J., Advanced micro \& nanosystems Vol.3, Microengineering of metals and ceramics: Part I: Design, tooling, and injection molding (2005a), Wiley-VCH.

Löhe, D. and Haußelt, J., Advanced micro \& nanosystems Vol.4, Microengineering of metals and ceramics. Part II, Special replication techniques, automation, and properties (2005b), Wiley-VCH.

Nishiyabu, K., Kakishita, K. and Tanaka, S., Fabrication of micro-structured parts by resist-film insert metal injection molding and effects of particle size, Transactions of the Japan Society of Mechanical Engineers, Series A,Vol.76, No.761 (2010a) pp.75-80 (in Japanese).

Nishiyabu, K., Kakishita, K. and Tanaka, S., Effect of micro/nano powder ratio on the properties of copper sintered parts produced by metal injection molding, Transactions of the Japan Society of Mechanical Engineers, Series A, Vol.76, No.767 (2010b) pp.996-1001 (in Japanese).

Nishiyabu, K., Kakishita, K. and Tanaka, S., Fabrication of micro-structured parts by nano-imprint lithography sacrificial plastic mold insert MIM using nano-sized copper powder, Transactions of the Japan Society of Mechanical Engineers, Series A, Vol.77, No.780 (2011) pp.1378-1387 (in Japanese).

Nishiyabu, K., Micro metal powder injection molding, Some critical issues for injection molding, edited by Wang J., InTech, Chapter 5 (2012), pp.105-130.

Nishiyabu, K., Tanabe, D., Kanoko, Y. and Tanaka, S., Behavior of debinding and sintering in micron and submicron-sized copper powder injection molded parts, Transactions of the Japan Society of Mechanical Engineers, Series A, Vol.79, No.807 (2013) pp.1593-1603 (in Japanese).

Nishiyabu, K. and Kawakami, J., Replication of micro-structured imprint plastic mold via electro-spinning nanofiber process, Transactions of the JSME (in Japanese), Vol.81, No.824 (2015), DOI:10.1299/transjsme.14-00571.

Piotter, V., Micro Metal injection molding (MicroMIM), Handbook of metal injection molding, edited by Heaney D., Woodhead Publishing, Chapter 13 (2012), pp.307-337.

Ramakrishna, S., An introduction to electrospinning and nanofibers (2005), World Scientific Publishing Company. Yamashita, Y., Electrospining the latest in nanotechnology -The creative of nanofibers-, SEN-I SHA (2007) (in Japanese). Wendorff, J.H., Agarwal, S. and Greiner, A., Electrospinning: materials, processing, and applications (2012), Wiley-VCH. 